\title{
HUBUNGAN TINGKAT KECEMASAN DENGAN HASIL PENALTY STROKE PADA PERMAINAN HOKI (STUDI DESKRIPTIF PADA UKM HOKI UNIVERSITAS MAJALENGKA)
}

\author{
Endi Rustandi \\ Universitas Majalengka, Indonesia \\ endirustandi79@gmail.com
}

\begin{abstract}
ABSTRAK. Kegagalan dalam melakukan penalty stroke masih banyak terjadi di UKM hoki Universitas Majalengka, hal ini diindikasi karena teknik dorongan yang masih kurang dan dipengaruhi juga oleh faktor psikologis yaitu tingkat kecemasan. Maka dari itu tujuan penelitian ini yaitu untuk mengetahui seberapa besar hubungan antara tingkat kecemasan terhadap hasil tembakan penalti pada permainan hoki. Metode penelitian yang digunakan dalam penelitian ini yaitu metode deskriptif jenis korelasi, Populasi pada penelitian ini sebanyak 15 anggota UKM Hoki Universitas Majalengka dengan populasi yang berjumlah 15 orang diambil keseluruhan sebagai sampel dengan menggunakan sampel total yang berarti sampel dalam penelitian ini yaitu 15 orang. Pengumpulan data dilakukan dengan menggunakan kuesioner berupa angket kecemasan dan tes tembakan penalty pada permainan hoki. Kesimpulan dalam penelitian ini yaitu terdapat angka korelasi 0.561 berarti berada dikategori sedang yaitu antara 0.40 hingga 0.599 . Dari hasil uji hipotesis juga diketahui thitung $=2,439$. Sedangkan untuk menentukan ttabel dilihat dari tabel distribusi $\mathrm{T}$ dengan $\mathrm{dk}=15-2=13$ untuk kesalahan $5 \%$ melalui uji dua pihak, pada taraf signifikan diperoleh ttabel $=2,160$. Maka daripada itu hipotesis diketahui ternyata thitung lebih besar dari ttabel $(2,439>2,160)$ dengan demikian hipotesis yang peneliti ajukan dalam penelitian ini dapat diterima. Bahwa terdapat hubungan yang positif antara tingkat kecemasan dengan hasil penalty stroke pada permainan hoki di UKM hoki Universitas Majalengka.
\end{abstract}

Kata Kunci: Kecemasan, Penalty Stroke dan Permainan Hoki

\section{Pendahuluan}

Menurut Aming (2008), "Hal yang penting dari permainan hoki adalah merasakan bahwa stik hoki seolah-olah sambungan dari tangan kita, sehingga dapat mengoper atau menyetop bola secara otomatis sesuai dengan perasaan kita.”

Penalty stroke adalah sebuah kesalahan yang disebabkan karena melakukan kesalahan di dalam area circle bila seorang pemain yang bertahan dengan jelas menghalangi sebuah bola yang akan masuk dengan cara yang tidak dibenarkan. Penalty stroke dilakukan dari jarak 6.4 meter (7 yard) dari depan gawang. Pemain-pemain lainnya harus berada di belakang garis 25 yard atau diluar area circle.

Selain yang terlibat dalam pelaksanaan penalty stroke, untuk setiap pelanggaran yang dilakukan oleh pemain bertahan dan gol tidak tercipta atau oleh penyerang dan gol tercipta, maka penalty stroke harus dilaksanakan kembali.

Kemungkinan besar untuk terciptanya gol dalam penalty stroke sangatlah besar, akan tetapi ada beberapa faktor yang mempengaruhi gagalnya penalty stoke untuk dijadikan menjadi gol, menurut Kurnaedi (2010) mengatakan bahwa "aspek-aspek psikologis yang berperan 
dalam olahraga diantaranya yaitu berfikir positif, emosi, motivasi, kepercayaan diri, konsentrasi dan kecemasan”.

Menurut Kurnaedi (2010) "Berfikir positif dimaksudkan sebagai cara berfikir yang mengarahkan sesuatu kearah positif. Pikiran positif akan diikuti dengan tindakan dan perkataan yang positif pula, karena pikiran akan menuntun tindakan.” Bilamana fikiran kita positif pada saat bertanding atau latihan apalagi pada saat akan melakukan penalty stroke yang menentukan terciptanya gol maka akan berpengaruh terhadap tindakan atau teknik yang atlet miliki.

Kecemasan merupakan hal yang sering kita temui didalam kehidupan setiap orang, seperti ahli ilmu mengatakan, "to be without fear would be a sign of disorded personality." (Cratty: 1973) yang artinya hanya orang-orang yang kurang waras yang tidak pernah takut.” Dari pendapat Cratty dapat disimpulkan bahwa semua manusia normal pasti memiliki tingkat kecemasan masing-masing, baik itu rendah, sedang, berat ataupun panik.

Setelah peneliti mengamati kegiatan latihan di UKM hoki Universitas Majalengka ternyata dalam teknik latihan penalty stroke tidak semua atlet bisa melakukan penalty stroke dengan baik, hal ini dikarenakan teknik dalam melakukan dorongan bola (shooting) masih kurang dan bisa juga karena aspek psikologis atlet terganggu seperti kurang percaya diri dan tingkat kecemasannya masih tinggi. Masalah ini belum teruji maka dari itu peneliti ingin mengetahui seberapa besar hubungannya tingkat kecemasan dengan hasil penalty stroke pada permainan hoki di UKM hoki Universitas Majalengka. Berdasarkan masalah diatas, peneliti tertarik untuk mengetahui apakah ada hubungan yang signifikan antara tingkat kecemasan dengan hasil penalty stroke pada permainan hoki di UKM hoki Universitas Majalengka.

\section{Hakikat Kecemasan (ANXIETY)}

Anxiety adalah salah satu gejala psikologis yang identik dengan perasaan negatif. Kecemasan dapat timbul kapan saja dan salah satu penyebab terjadinya kecemasan adalah ketegangan yang berlebihan yang berlangsung lama. Kecemasan adalah reaksi situasional terhadap rangsang stress (Straub, 1978, Husdarta, 2010).

Menurut Weinberg \& Gould (2003) dalam Mylsidayu (2014) menyatakan bahwa anxiety adalah keadaan emosi negative yang ditandai dengan gugup, khawatir, dan ketakutan dan terkait dengan aktivasi atau kegairahan pada tubuh. Pada gejala cemas biasanya didominasi oleh keluhan-keluhan psikis (ketakutan dan kekhawatiran), tetapi dapat pula disertai keluhan somatic (fisik). Kecemasan dapat didefininisikan suatu keadaan perasaan keprihatinan, rasa gelisah, ketidak tentuan, atau takut dari kenyataan atau persepsi ancaman sumber aktual yang tidak diketahui atau dikenal . 
Kecemasan adalah suatu keadaan yang ditandai dengan perasaan ketakutan yang disertai dengan tanda somatik yang menyatakan terjadinya hiperaktifitas sistem syaraf otonom. Kecemasan adalah gejala yang tidak spesifik yang sering ditemukan dan sering kali merupakan suatu emosi yang normal (Kusuma W, 1997).

\section{Pengertian Olahraga Hoki}

Menurut Aming dan Entang (2008) "Hoki adalah olahraga permainan yang dilakukan pria dan wanita dengan menggunakan alat pemukul (stick) dan bola”. Hoki merupakan olahraga beregu maka perlu adanya kerja sama tim untuk meraih kesuksesan. Akan tetapi dituntut pula adanya kemampuan dari setiap individu pemain dalam menguasai teknik-teknik dasar yang baik. Menurut Aming (2008), Hal yang penting dari permainan hoki adalah merasakan bahwa stik hoki seolah-olah sambungan dari tangan kita, sehingga dapat mengoper atau menyetop bola secara otomatis sesuai dengan perasaan kita.

Olahraga hoki terbagi menjadi dua jenis area lapangan yaitu hoki lapangan (field) dan hoki ruangan (indoor). Dalam peraturannya itu sendiri memiliki perbedaan hoki ruangan mempunyai peraturan tersendiri yang tentunya tidak sama dengan hoki lapangan. Perbedaan peraturan permainan tersebut dapat dilihat dari jumlah pemain dari tim yang bertanding, dalam hoki ruangan tiap tim terdiri dari 12 pemain, 5 pemain inti dan 7 pemain cadangan, sedangkan dalam hoki lapangan setiap tim terdiri dari 16 pemain, 11 pemain inti dan 5 cadangan. Waktu pertandingan pun untuk hoki ruangan itu 2 x 15 menit sedangkan hoki lapangan (outdoor) 2 x 35 menit untuk putera dan puteri 2 x 20 menit. Di dalam hoki ruangan sendiri dilarang untuk memukul bola (hit) sedangkan di hoki lapangan hit diperlukan untuk hasil shooting yang keras.

\section{Teknik Dasar Permainan Hoki}

Ada beberapa teknik yang dapat dipelajari dalam permainan ini seperti teknik passing (mengumpan bola), dribbling (menggiring bola), shooting (menembak bola ke gawang) dan stopping (menghentikan bola).

Passing dalam permainan hoki terdiri dari push, tapping dan hit, Passing merupakan teknik dasar dalam permainan hoki yang tujuannya untuk mengumpan jarak dekat dengan stik ditempelkan ke bola. Dalam passing push ada hal penting yang harus diperhatikan yaitu akurasi, kecepatan gerakan dan mengubah arah bola.

Tapping merupakan teknik dasar pada olahraga hoki yang mana merupakan teknik mengumpan seperti teknik push. Namun pada teknik ini terdapat point contact antara bola 
dengan stick, jadi terdapat ayunan dalam melakukannya. Berbeda dengan teknik push yang mana bola denga stick menempel kemudian memberikan dorongan.

Memukul (hit) adalah teknik memindahkan bola secara cepat dan tepat, baik umpan jauh ataupun untuk menciptakan skor. hit merupakan teknik serang cepat yang akan membuat lawan kesulitan untuk mengantisipasi bola yang datang. Aspek penting hit adalah untuk mengumpan atau menciptakan skor dengan cepat dan akurat.

Stoping merupakan teknik dalam permainan hoki yang menghentikan bola ketika bola sedang berjalan. Tujuan dari teknik ini yaitu untuk mengontrol dan memotong laju bola.

Dribbling dalam permainan hoki merupakan teknik dasar menguasai bola dengan berlari yang tujuannya untuk mengecoh, menarik lawan dari posisinya, dan untuk mendapatkan ruang gerak untuk melakukan operan atau tembakan. Dribble terdiri dari loose (melepaskan bola), close (bola ditutup dengan wajah stik) dan Indiana (buka tutup/zig-zag).

Menembak (shooting) adalah keterampilan khusus yang membutuhkan latihan secara berulang-ulang.dalam permainan hoki sama halnya dengan permainan yang lain yaitu untuk mengarahkan bola ke gawang dan menciptakan gol. Shooting dalam permainan hoki terdiri dari chip shoot (menaikan bola), drag flick shoot (menembak dengan dorongan kuat). Namun ketika didalam circle teknik push, hit dan tapping bisa diterapkan bahkan lebih efektif karena gerakannya yang spontan.

\section{Teknik Dasar Dorongan Bola dalam Melakukan Penalty Stroke}

Penalty stroke adalah satu tembakan bebas yang dilakukan dengan satu dorongan jarak (push) atau menyentrik bola (flick) pada suatu titik dari depan gawang dengan jarak $6.5 \mathrm{~m}$ dari garis tengah gawang, sebagai hukuman dari pelanggaran keras yang dilakukan didalam daerah setengah lingkaran oleh pemain bertahan terhadap pemain penyerang lawan. Pemain yang melakukan tembakan penalty hanya diijinkan melakukan satu langkah dan mengangkat bola, hanya dengan satu kali sentuhan. Teknik dasar yang biasa digunakan oleh para pemain dalam melakukan tembakan pinalti adalah push atau flick.

Push adalah salah satu teknik dasar dalam hoki yang biasa digunakan dalam melakukan operan bola (passing), namun teknik ini dapat digunakan dalam melakukan tembakan (shooting) terutama di dalam daerah setengah lingkaran saat permainan berlangsung atau pada saat melakukan tembakan penalti tentunya dengan kecepatan yang tinggi dan akurasi penempatan bola yang tepat pada tempat yang sulit dijangkau penjaga gawang. Saat melakukan gerakan push tangan harus menggenggam stik dengan nyaman, tangan kiri berada di atas pada puncak stik, sedangkan tangan kanan berada dibawahnya dengan jarak kira-kira sepertiga 
sampai dengan setengah dari panjang stik normal. Posisi tangan kanan yang diturunkan dimaksudkan untuk memberikan kontrol yang lebih besar. Genggaman tangan pada stik harus kuat, tubuh dalam posisi membungkuk dengan menekuk kedua lutut. Kaki sebelah kiri dan bahu harus menunjukan pada arah jalannya bola. Posisi stik harus dipertahankan sampai selesai melakukan dorongan terhadap bola sampai mencapai sasaran yang diinginkan atau sejalan dengan alur dari bola. Koordinasi gerakan dilakukan dalam waktu yang bersamaan setelah ada aba-aba dari wasit, Berat badan dipindahkan dari tumpuan awal pada kaki kanan ke kaki kiri dengan melangkahkan kaki kiri pada saat gerakan mulai dilakukan. Dorongan bola dilakukan dengan kekuatan maksimal untuk memperoleh kecepatan yang tinggi, ketepatan sasaran dilakukan dengan fokus pada sasaran untuk memperoleh akurasi yang tinggi pada daerah yang sulit dijangkau penjaga gawang lawan.

\section{Metode Penelitian}

Metode yang digunakan dalam penelitian ini yaitu metode penelitian deskriptif jenis korelasi. Menurut Iskandar (2013) "Tujuan penelitian korelasi adalah untuk mengetahui hubungan antara dua variabel atau lebih, atau hubungan antara variabel bebas dengan variabel terikat". Sedangkan menurut Syaodih (2010) "penelitian deskriptif adalah metode penelitian yang ditujukan untuk menggambarkan fenomena yang ada yang berlangsung pada saat ini atau masa lampau".

Jadi, penelitian ini bermaksud untuk mengetahui gambaran tentang ada tidaknya hubungan antara tingkat kecemasan dengan hasil penalty stroke pada permainan hoki di UKM hoki Universitas majalengka berdasarkan data yang diperoleh dan diolah secara statistik.

Dalam penelitian ini Populasi atau wilayah data yang menjadi subjek penelitian ini yaitu UKM hoki Universitas Majalengka dengan jumlah populasi 15 orang. Kenapa di UKM hoki Majalengka, Hal ini dikarenakan olahraga hoki yang ada disekitar wilayah III cirebon hanya ada di Majalengka dan juga mengingat jarak yang mudah terjangkau untuk peneliti dalam melakukan penelitian, maka dari itu peneliti mengambil populasi di UKM hoki Universitas Majalengka.

Dalam penelitian ini teknik sampling yang akan digunakan yaitu Non-Probability sampling dengan cara sampling total. "Nonprobability Sampling adalah teknik pengambilan sampel yang tidak memberi peluang/kesempatan sama bagi asetiap unsur atau anggota populasi untuk dipilih menjadi sampel." Sugiyono (2013). Sedangkan jenis yang digunakan dari Nonprobability Sampling yang digunakan yaitu dengan sampling total. Menurut Badriah (2012: 110) "sampling total biasa dilakukan pada penelitian-penelitian kasus yang spesifik dan sangat 
homogeni karakteristik dan populasinya, jumlah populasi biasanya kurang dari 30 subyek sehingga populasi penelitian tersebut secara otomatis menjadi sampel penelitian." Maka dari itu semua anggota populasi dengan jumlah 15 atlet yang ada di UKM hoki Universitas Majalengka dijadikan sampel dalam penelitian ini. Sehingga sampel dalam penelitian ini yaitu berjumlah 15 orang.

Teknik pengumpulan data yang diperlukan disini adalah teknik pengumpulan data yang mana paling tepat sehingga benar-benar didapat data yang valid dan reliable. Dalam pengumpulan data peneliti menggunakan instrument berupa angket dan tes kemampuan melakukan penalty stroke pada permainan hoki.

Instrumen yang digunakan dalam penelitain ini adalah dengan menggunakan kuesioner berupa angket dan survey dengan teknik tes dan pengukuran.

Angket dalam penelitian ini digunakan untuk mengetahui tingkat kecemasan atlet pada saat melakukan penalty stroke di UKM hoki Universitas Majalengka. Dalam penyusunan kuesioner tersebut terlebih dahulu peneliti menentukan indikator yang menjadi landasan dalam pembuatan beberapa yang mana menurut Weinberg \& Gould (2003) dalam Mylsidayu (2014) menyatakan bahwa kecemasan adalah keadaan emosi negatif yang ditandai dengan gugup, khawatir dan ketakutan dan terkait dengan aktivasi atau kegairahan pada tubuh, pada gejala cemas biasanya didominasi oleh keluhan-keluhan psikis akan tetapi dapat pula disertai keluhan fisik.

Adapun langkah-langkah yang ditempuh untuk menyusun kuesioner adalah:

1) mengidentifikasi variabel-variabel dalam rumusan penelitian

2) mengembangkan variabel-variabel ke dalam konstruk dimensi yang mana yang dapat dikaji dalam teori yang telah dirumuskan oleh peneliti.

3) Merumuskan kisi-kisi instrument

Sebelum digunakan untuk mengumpulkan data, angket ini diuji cobakan terlebih dahulu. Pelaksanaan uji coba yang dimaksud untuk mengetahui nilai validitas dan reliabilitas alat ukur yang telah disusun sehingga diketahui valid dan tidaknya alat ukur tersebut dipergunakan sebagai alat pengukuran data. Setelah pengujian skala selanjutnya dilakukan pengujian validitas, hal ini dilakukan untuk mengetahui tingkat kesahihan tes yang dilakukan. Adapun langkah-langkah pengerjaan yang dilakukan yaitu menggunakan program SPSS 16 for windows.

Sedangkan untuk tes kemampuan penalty stroke, peneliti sebelum melakukan tes penalty kasih arahan untuk membangkitkan kecemasan dengan memberikan penekanan bahwa latihan kali ini akan diadakan seleksi kembali untuk kejuaraan antar daerah berikutnya, bukan 
hanya latihan fisik, teknik maupun dalam bermain melainkan nanti akan diuji mental dengan melakukan penalty stroke. jika melakukan penalti tidak sempurna ancamannya tidak akan diikutkan kembali dalam acara kejuaraan yang akan datang, dan juga tentunya mendatangkan pelatih beserta jajarannya supaya menambah tingkat kecemasan pada atlet yang akan latihan, karena sebelumnya setiap latihan pelatih jarang turun langsung dikarenakan waktu dan jarak yang mungkin jadi kendala beliau. Namun peneliti setelah amati dilapangan ketika pelatih memantau latihan para atlet berbeda ketika latihan sendiri dan pelatih hal ini dikarenakan karena pelatih lebih menekankan atlet untuk mampu melakukan instruksi yang dia berikan sehingga atlet merasa ada perasaan takut akan gagal dan rasa kepercayaan diri mereka berkurang. Disamping mendatangkan pelatih peneliti juga mengkondisikan penekanan kecemasan dengan ditonton banyak orang ketika latihan yaitu latihan di lapangan kampus supaya dapat meningkatkan kecemasan dengan dilihat banyak orang.

Tes kemampuan penalty stroke tujuannya untuk mengetahui kemampuan teknik melakukan pinalti pada permainan hoki. Berikut tata cara melakukan tes tembakan penalty stroke pada permainan hoki menurut Nurhidayah (2013):

1) Testee adalah pemain yang sudah dapat melakukan tembakan penalti.

2) Testee bersiap melakukan pukulan, pada aba - aba "SIAP", testee sudah berdiri disamping titik penalti dengan stik ditangan dan bola terletak tepat di titik penalti yang berjarak 6 meter dari garis tengah gawang. Dengan aba - aba "YA" testee mulai melakukan gerakan.

3) Tes dilakukan 3 kali berturut - turut

4) Sasaran dari tembakan penalti ini adalah pojok atas kanan dan kiri gawang.

Semakin keatas dan kepojok gawang skornya akan semakin tinggi hal ini dikarenakan jika bola kebawah posisi kiper akan mudah untuk menghalanginya namun bilamana bola naik keatas kiper sulit untuk menjangkaunya hal ini dikarenakan posisi tangan untuk menghalangi laju bola hanya stik dan sarung guard tangan yang lebarnya sedikit, berbeda jika dengan menggunakan kaki dengan guard yang mudah untuk menghadang hanya dengan menurunkan kaki bola bisa dihadang.

Pelaksanaan analisis data penelitian, setelah data diperoleh dari hasil pengukuran selanjutnya analisis dengan teknik regresi. Namun sebelum melakukan uji analisis terlebih dahulu dilakukan sejumlah uji persyaratan untuk mengetahui kelayakan data. Adapun uji persyaratan tersebut meliputi :
a) Uji Validitas
b) Uji Normalitas Data
c) Uji Analisis Korelasi 
d) Menentukan besar pengaruh

e) Pengujian Hipotesis Penelitian

\section{Hasil dan Pembahasan}

Penelitian ini bertujuan untuk mengetahui ada tidaknya hubungan yang signifikan antara tingkat kecemasan dengan hasil penalty stroke pada permainan hoki di UKM hoki Universitas Majalengka. Dalam hal ini hubungan antara tingkat kecemasan dengan hasil penalty stroke yang peneliti temukan dilapangan yaitu ternyata dari setiap sampel memiliki kemampuan spesialisnya masing-masing hal ini karena terbukti yang kelihatan teknik bermainnya sudah baik ternyata dalam melakukan penalty stroke tidak semua bola masuk kearah yang dituju bahkan ada yang penempatan bolanya tepat namun dorongannya lemah, ada juga dorongannya kuat tetapi arahnya masih kurang tepat. Hal ini bisa diantisipasi dengan program latihan pengulangan yang harus pelatih kasih untuk memperbaiki kemampuan dalam melakukan penalty stroke.

Setelah peneliti mengumpulkan data berupa instrument kuesioner dan tes penalty stroke dan kemudian diolah dan dianalisis ternyata mendapatkan hasil yang positif hal ini dapat dibuktikan dengan angka korelasi yang sampai 0.561 sehingga terdapat hubungan yang positif antara tingkat kecemasan dengan hasil penalty stroke pada permainan hoki di UKM hoki Universitas Majalengka.

Hal ini bisa dilihat dari angka korelasi yang sampai 0.561 berarti berada dikategori sedang yaitu antara 0.40 hingga 0.599 atau -0.40 hingga -0.599 . sedangkan pengaruh antara variabel X terhadap Variabel Y didapatkan angka sebesar 31,4\% dipengaruhi oleh variabel yang lain. Dari hasil uji hipotesis juga diketahui thitung $=2,349$. Sedangkan untuk menentukan ttabel dilihat dari tabel distribusi $\mathrm{T}$ dengan $\mathrm{dk}=15-2=13$ untuk kesalahan 5\% melalui uji dua pihak, pada taraf signifikan diperoleh ttabel $=2,160$. Maka daripada itu hipotesis diketahui ternyata thitung lebih besar dari ttabel $(2,439>2,160)$ maka hipotesis diterima. Maka daripada itu hal ini berrti terdapat hubungan yang positif dan nilai koefisien korelasi antara tingkat kecemasan dengan hasil penalty stroke pada permainan hoki sebesar 0.561 yang berarti berkorelasi sedang.

\section{Kesimpulan}

Setelah dilakukan penelitian dan menganalisis data dari hasil temuan, dapat disimpulkan sebagai berikut, setelah peneliti mengumpulkan data berupa instrument kuesioner dan tes penalty stroke dan kemudian diolah dan dianalisis ternyata mendapatkan hasil yang positif. Hal 
ini bisa dilihat dari angka korelasi yang sampai 0.561 berarti berada dikategori kuat yaitu antara 0.40 hingga 0.599 atau 0.40 hingga -0.599 .

Sedangkan pengaruh antara variabel X (tingkat kecemasan) terhadap Variabel Y (hasil penalty stroke) didapatkan angka sebesar 31,4\% dan lebihnya dipengaruhi oleh variabel yang lain. Dari hasil uji hipotesis juga diketahui thitung $=2,439$. Sedangkan untuk menentukan ttabel dilihat dari tabel distribusi $\mathrm{T}$ dengan $\mathrm{dk}=15-2=13$ untuk kesalahan 5\% melalui uji dua pihak, pada taraf signifikan diperoleh ttabel $=2,160$. Maka daripada itu hipotesis diketahui ternyata thitung lebih besar dari ttabel $(2,439>2,160)$ maka hipotesis diterima. Maka daripada itu hal ini berarti terdapat hubungan yang positif dan nilai koefisien korelasi antara tingkat kecemasan dengan hasil penalty stroke pada permainan hoki sebesar 0.561 yang berarti berkorelasi sedang.

\section{Daftar Pustaka}

Amirullah. (2013). Buku Modul Statistika. Majalengka

Badriah, D. L. (2012). Metodologi Penelitiann Ilmu-Ilmu Kesehatan (Cetakan 5). Bandung: Multazam. Gunarsa, Singgih D. 2008. Psikologi Olahraga Prestasi. Jakarta: Gunung Mulia

Iskandar. (2013). Metodologi Penelitian Pendidikan dan Sosial (Cetakan 5). Jakarta: Referensi

Kurnaedi, E. (2010). Hand Out Psikologi Olahraga. Majalengka : Universitas Majalengka Mylsidayu, A. (2014). Psikologi Olahraga. Jakarta: Bumi Aksara

Nurhidayah, E. (2013). Sumbangan Power Otot Lengan, Kekuatan Genggaman, Fleksibilitas Pergelangan Tangan Dan Kekuatan Tungkai Terhadap Kemampuan Tembakan Penalty Hockey. (Skripsi). Universitas Negeri Semarang, Semarang

Penataran Wasit Hockey Pengurus Provinsi Jabar. Bandung Sugiyono. (2014). Statistika Untuk Penelitian. Bandung: ALFABETA

Sugiyono. (2015). Metode Penelitian Pendidikan. Bandung: ALFABETA

Supriyatna, A. \& Hermanu, E. (2008). Modul Pelatihan Cabang Olahraga Hoki. Bandung: UPI Tim Pengajar Hoki PJKR. (2012). Pembelajaran Permainan Hoki. Bandung: UPI http://mantrigilang.blogspot.com/2012/07/konsep-dasar-kecemasan.html http://wengayo.blogspot.com/2010/06/analisis-gerakan-dorongan-bolapush.html 